\title{
A quest in neurosciences: neuroportraits
}

\author{
Nicholas Wade • Bernd Nilius • Marco Piccolino
}

Received: 8 April 2011 / Accepted: 8 April 2011 /Published online: 28 April 2011

(C) Springer-Verlag 2011

Electrophysiology - more than a method but a programme for studying molecular, cellular and even macroscopic organic events - was and is always one of the main corner stones of Pflüger's Archiv! We will attract excellent papers in this field and will also attract more papers from neurosciences, as some special issues in the near future will prove. This ambition is based also on 'tradition' as seminal electrophysiological papers were published in Pflüger's Archiv [1]. There is no future without the recognition of history! Do we accept this truth also in science? With this editorial, we will tempt our readers to trace in 'the sessions of sweet silent thought' some roots of electrophysiology, neurophysiology, and the history of discovery of electrical events in biological systems. A fascinating journey!

For this reason, we will offer our readers access to a highly interesting collection: the 'neuroportraits'. 'Perceptual portraits' like those in Fig. 1 can be seen at a new website devoted to the history of neuroscience (http://neuroportraits.eu/). The intention of the website is to stimulate interest in the history of neuroscience visually. Perceptual portraits represent people in an unconventional style. They generally consist of at least two

\footnotetext{
N. Wade $(\bowtie)$

School of Psychology, University of Dundee,

Dundee DD1 4HN, UK

e-mail: n.j.wade@dundee.ac.uk

B. Nilius

KU Leuven, Campus Gasthuisberg, Department Molecular Cell Biology, Lab Ion Channel Research,

3000 Leuven, Belgium

\section{Piccolino}

Dipartimento di Biologia ed Evoluzione - Sezione di Fisiologia Generale, Università di Ferrara,

44100 Ferrara, Italy
}

elements - the portrait and some appropriate motif. The nature of the latter depends upon the endeavours for which the portrayed person was known. In some cases the motif was drawn specifically to display a phenomenon associated with the individual, in others it was derived from a figure or text in one of their books, or apparatus which they invented. The portraits and motifs have themselves been manipulated in a variety of ways, using graphical, photographical and computer graphical procedures. The illustrations often require some effort on the part of the viewer to discern the faces embedded in them. The visual intrigue can enhance the viewer's desire to discover why particular motifs have been adopted, and in turn to learn more about the persons portrayed: neuroportraits are intended to be examples of art serving science.

The origins of physiology can be traced back to Jean Fernel (1497-1558) who introduced the term in his Physiologia which was part of his Universa Medica. The subject blossomed in the nineteenth century and was greatly assisted when Pflüger (Fig. 1, left) founded this journal in 1868 [2, 3]. Articles by no lesser figures than Bernstein, Helmholtz, Panum, Donders, Aubert and Exner can be found in volume 1. Indeed, it was in this volume that the first measurements of the speed and waveform of action potentials were presented by Bernstein (Fig. 1, right). The origins of neuroscience are less easy to trace. The term was introduced by Francis Otto Schmitt in the 1960s, but the endeavour itself is much more ancient. It reflects the work of many who conspired to illuminate the structure of the nervous system, the manner of communication within it, its links to reflexes and its relation to more complex behaviour, as well as to perceptual experience. Now, the prefix 'neuro' is applied to almost everything! Despite this widespread use, neuroscience is seldom accorded a definition of any detail. It thrives on its vague appeal to advances that are 


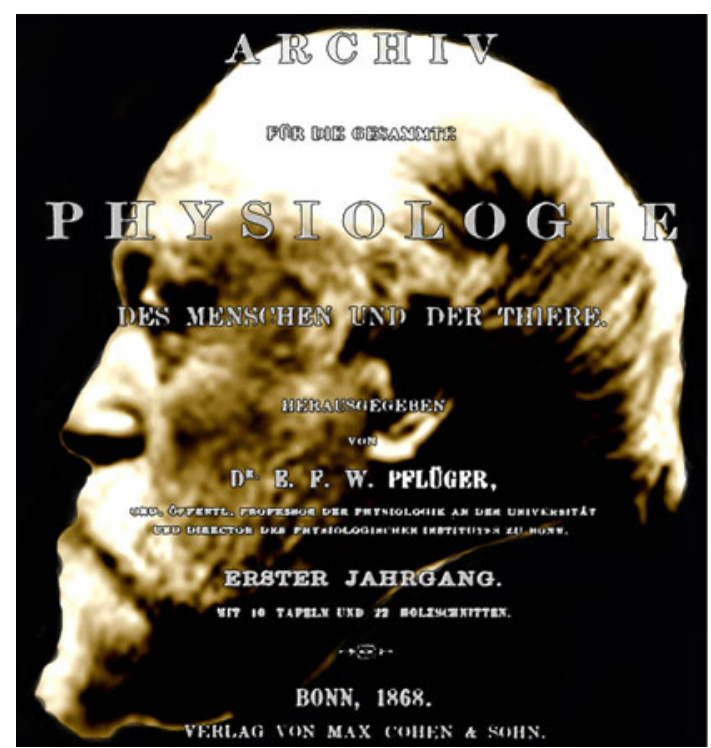

Fig. 1 Left, Eduard Friedrich Wilhelm Pflüger (1829-1910) is shown in combination with the title page of the first volume of what became known as his Archiv. Right, Julius Bernstein (1839-1917) is dimly

being achieved in studies of the nervous system, and as such the origins of neuroscience stretch back to antiquity. The neurosciences emerged from the biological sciences because conceptual building blocks were isolated, and the ways in which they can be arranged were explored. The foundations on which the structure could be securely based were the cell and neuron doctrines on the biological side, and morphology and electrophysiology on the functional side.

Physiology made particularly large strides in the nineteenth century. It emerged as a science on the wave of the investigations of the electric nature of muscle and nerve excitability in frog preparations made by Galvani at the end of the previous century. Galvani's experiments had been inspired by previous research on the shocks delivered by certain fish; they were recognised to be electrical by several amateur natural philosophers like John Walsh. In the first half of the nineteenth century, Matteucci (whose bicentenary is being celebrated this year) succeeded in measuring the 'animal electricity' with a physical instrument and provided evidence of its biological origin. Matteucci's research heralded great progress in electrophysiology and the subject flourished in German universities, with the studies of celebrated scholars such as du Bois-Reymond, Helmholtz, Pflüger, Hermann and many others, culminating in Bernstein's 'membrane theory'. For young modern neuroscientists, these studies probably represent the watershed between what is considered contemporary science and what is seen as its historical background, perceived in distant and somewhat cloudy perspective. However, 'we cannot clearly be aware of what we possess till we have the means of knowing what others possessed before us. We cannot really and honestly

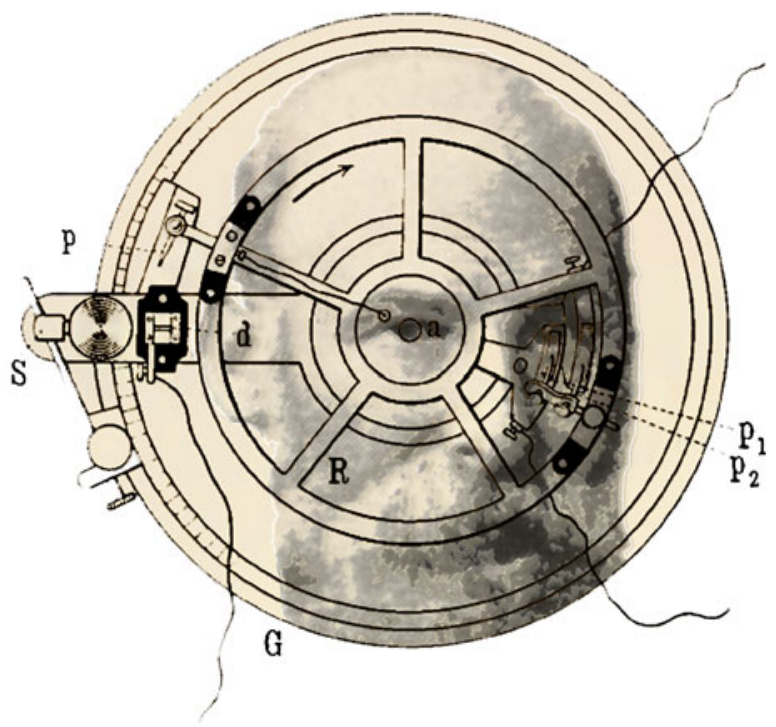

discernable in the diagram of his Differentialrheotom used for measuring action potentials; it was illustrated in the first volume of the Archiv

rejoice in the advantages of our own time if we do not know how to appreciate the advantages of former periods'. These words, which underline the importance of the past for the enjoyment and comprehension of the present, were uttered by a great poet, Johann Wolfgang von Goethe. He was so deeply immersed in science that he considered his achievements in this field more important than his famous poetic creations. They also provide the opening quotation in the introduction to http://neuroportraits.eu/, the construction of which was supported by the Federation of the European Neuroscience Societies. All the individuals mentioned in this editorial, and many more, are portrayed and their visages are combined with aspects of their contributions to physiology, especially electrophysiology and neuroscience, like the portraits of Pflüger and Bernstein in Fig. 1. By combining electrophysiology and neuroscience with its history, we wish to go beyond the narrow technicalities of modern research and aim at recovering the great intellectual attraction that the scientific enterprise held in former periods.

\section{References}

1. Hamill OP, Marty A, Neher E, Sakmann B, Sigworth FJ (1981) Improved patch-clamp techniques for high-resolution current recording from cells and cell-free membrane patches. Pflügers Arch 391:85-100

2. Nilius B (2003) Pflugers Archiv and the advent of modern electrophysiology. From the first action potential to the patch clamp. Pflügers Arch 447:267-271

3. Nilius B (2011) Why do we not change a journal's name? Pflügers Arch 461:207-209 